\title{
Efektifitas Sayur Pepaya Muda dan Sayur Daun Kelor terhadap Produksi ASI pada Ibu Post Partum Primipara
}

\author{
Warjidin Aliyanto $^{1}$, Rosmadewi ${ }^{2}$ \\ ${ }^{1,2}$ Jurusan Kebidanan, Politeknik Kesehatan Tanjungkarang, Indonesia \\ Email: ros29madewi@gmail.com
}

\begin{abstract}
Effectiveness of Young Papaya Leaves and Moringa Leaf Vegetables on Breast Milk Production in Primipara Postpartum Mothers. Mother's milk (ASI) have a role a very important role in the baby's growth process that starts from the beginning of its birth, so it is expected that breast milk production in postpartum mothers can meet the needs of babies at the beginning of their lives. The problem this study was that $54 \%$ of primipara postpartum mothers had not yet produced breast milk on day 3 or 4. According to Istiqomah et al (2015), Zakaria's research (2016), the papaya fruit and Moringa leaf act as Laktogogum which can increase milk production and facilitate breast milk expenditure. This study aims to determine the effectiveness of consumption of young papaya leaves and Moringa leaf vegetables on breast milk production in postpartum primipara mothers in the independent practice of midwives. The indicators used to determine breast milk production are seen from baby weight gain at 30 days first life. This type of research is quantitative research using the Quasi-experimental design, namely Non-Equivalent Control Group Design. The subjects were 90 primiparous postpartum mothers. Data collection uses primary data. Analysis using the Independent Sample T-Test. The results showed increased breast milk production in primipara postpartum mothers who consumed young papaya vegetables seen from the average increase in baby weight at 30 days at 930 grams and primipara postpartum mothers who consumed kelor leaf vegetables on average baby weight gain 1270 gram. Whereas in primipara postpartum mothers who did not consume young papaya and kelor leaf vegetables, the average increase in body weight of infants aged 30 days were 847 grams. There was a significant difference in breast milk production in primiparous postpartum mothers between those who consumed young papaya vegetables and Moringa leaf vegetables to increase infant weight at 30 days with p-value 0.001 . As for effectiveness, consumption of vegetable Moringa leaves is more effective at increasing the baby's weight at 30 days of age compared to consuming young papaya vegetables.
\end{abstract}

Keywords: Baby weight, Breast milk production, Moringa leaves

\begin{abstract}
Abstrak: Efektifitas Sayur Pepaya Muda dan Sayur Daun Kelor terhadap Produksi ASI pada Ibu Post Partum Primipara. Air Susu Ibu (ASI) sangat berperan dalam proses pertumbuhan bayi yang dimulai sejak awal kelahirannya, sehingga diharapkan produksi ASI pada ibu post partum dapat mencukupi kebutuhan bayi pada awal kehidupannya. Masalah penelitian didapatkan $54 \%$ ibu post partum primipara produksi ASI nya belum keluar pada hari ke 3 atau ke 4 . Menurut Istiqomah dkk (2015) dan Zakaria dkk (2016), bahwa buah pepaya dan daun kelor berperan sebagai Laktogogum yang dapat meningkatkan produksi ASI dan memperlancar pengeluaran ASI. Penelitian bertujuan mengetahui efektifitas konsumsi sayur pepaya muda dan sayur daun kelor terhadap produksi asi pada ibu post partum primipara. Indikator yang digunakan untuk mengetahui produksi ASI dilihat dari penambahan berat badan bayi pada 30 hari pertama kehidupannya. Jenis penelitian kuantitatif dengan desain Quasi eksperiment yaitu Non Equivalent Control Group Design. Subjek penelitian ibu post partum primipara sejumlah 90 orang. Pengumpulan data menggunakan data primer. Analisis menggunakan Uji T Sampel Independent. Hasil penelitian produksi ASI meningkat pada ibu post partum primipara yang mengkonsumsi sayur pepaya muda dilihat dari rata-rata kenaikan berat badan bayi pada usia 30 hari yaitu 930 gram dan ibu post partum primipara yang mengkonsumsi sayur daun kelor rata-rata kenaikan berat badan bayi 1270 gram. Sedangkan pada ibu post partum primipara yang tidak mengkonsumsi sayur pepaya muda dan sayur daun kelor rata-rata kenaikan berat badan bayi usia 30 hari 847 gram. Ada produksi ASI pada ibu post partum primipara antara yang mengkonsumsi sayur pepaya muda dan sayur daun kelor terhadap penambahan berat badan bayi pada usia 30 hari dengan $p$ value 0,001 . Sedangkan untuk efektifitas, konsumsi sayur daun kelor lebih efektif meningkatkan berat badan bayi pada usia 30 hari dibandingkan dengan mengkonsumsi sayur pepaya muda.
\end{abstract}

Kata kunci: Berat badan bayi, Produksi ASI, Daun Kelor 


\section{PENDAHULUAN}

Sustainable Development Goals (SDGs) atau Tujuan Pembangunan Berkelanjutan 2030, menyusui merupakan salah satu langkah pertama bagi seorang manusia untuk mendapatkan kehidupan yang sehat dan sejahtera. Sayangnya, tidak semua orang mengetahui hal ini. Di beberapa negara maju dan berkembang termasuk Indonesia, banyak ibu karir yang tidak memberikan ASI kepada bayinya karena produksi ASI berkurang akibat dampak dari kualitas makanan yang dikonsumsinya. Saat ini para ibu primipara terbiasa makan makanan yang siap saji yang merupakan kebiasaan yang mereka lakukan sebelum menjadi ibu.

Di Indonesia hampir 9 dari $10 \mathrm{ibu}$ pernah memberikan ASI, namun penelitian IDAI menemukan hanya $49,8 \%$ yang memberikan ASI secara ekslusif selama 6 bulan sesuai rekomendasi WHO (Fadhila \& Ninditya, 2016, dalam Oktova, 2017). Rendahnya cakupan pemberian ASI eksklusif ini dapat berdampak pada kualitas hidup generasi penerus bangsa dan juga pada perekonomian nasional. Masih rendahnya angka pencapaian ASI eksklusif tentu saja perlu mendapat perhatian karena berkontribusi terhadap rendahnya kualitas sumber daya manusia di masa mendatang serta berdampak pula terhadap tingginya angka kesakitan maupun angka kematian (Salfina, Elmida, 2003).

Beberapa tujuan SDGs yang sangat berkaitan erat dengan produksi ASI antara lain: (1) Menyusui merupakan sumber nutrisi terbaik dengan komposisi bioaktif yang dapat meningkatkan status kesehatan ibu dan anak, hal ini sejalan dengan tujuan SDGs nomor 2 dan 3 yaitu penanggulangan kelaparan, masalah kesehatan dan kesejahteraan. (2) Bayi yang mendapatkan ASI dengan standar emas makanan bayi terbukti memiliki IQ lebih tinggi dan performa lebih baik sehingga memiliki pekerjaan dan penghasilan yang layak, sehingga tentu saja berkesinambungan dengan tujuan SDG nomor 4 yaitu menjamin pemerataan pendidikan yang berkualitas. (3) Menyusui pula dapat menekan pengeluaran untuk membeli kebutuhan susu formula, sehingga lebih hemat dan ramah lingkungan, sejalan dengan tujuan SDGs nomor 12 yaitu konsumsi yang bertanggung jawab.

Pada masa bayi usia 0-6 bulan, kebutuhan nutrisi bayi sangat tergantung terhadap air susu dari ibunya (ASI). Pemberian ASI sebagai makanan pertama bayi yang berusia dibawah 6 bulan merupakan hal yang sangat diperhatikan karena bayi sebaiknya hanya diberikan ASI saja.
Hal ini sangat ketergantungan terhadap produksi ASI dari ibu pada periode menyusui.

Pada saat memperingati World Breastfeeding Week atau Pekan ASI Sedunia yang jatuh pada tanggal 1-6 Agustus 2017, Asosiasi Ibu Menyusui Indonesia (AIMI) merayakannya dengan dengan tema besar "Sustaining Breastfeeding Together" dengan semangat menekankan dukungan dari berbagai pihak agar mencapai kesuksesan menyusui, khususnya di Indonesia. Pekan ASI Sedunia selalu memberikan dukungan bagi para ibu, sebagai sosok pahlawan untuk anak, keluarga dan masyarakat, dan memberikan yang terbaik bagi anaknya untuk terus mengoptimalkan tumbuh kembang anak, salah satunya berupa pemberian Air Susu Ibu. Dalam rangka mengingatkan masyarakat betapa pentingnya air susu ibu (ASI) bagi tumbuh kembang bayi, setiap 1-6 Agustus warga dunia memperingati Hari ASI Sedunia dan dilaksanakan selama satu pekan. Ada 170 negara lebih yang telah menyelenggarakan pekan ASI sedunia dengan berbagai kegiatan, termasuk di Indonesia. Pekan ASI sedunia merupakan momen peringatan untuk membangun semangat para ibu untuk memberikan ASI, karena ASI memiliki peran penting dalam mendukung upaya perlindungan, promosi, dan dukungan menyusui bagi ibu dan si buah hati.

Berdasarkan data yang dikumpulkan International Baby Food Action Network (IBFAN) 2014, Indonesia menduduki peringkat ke tiga terbawah dari 51 negara di dunia yang mengikuti penilaian status kebijakan dan program pemberian makan bayi dan anak (Infant-Young Child Feeding) (Prasetyaningati, 2018). Hal Ini menunjukkan, pemberian ASI sebagai makanan pertama bayi masih kurang. Padahal, penurunan gizi anak hingga menyebabkan anak bergizi kurang hingga buruk dan tumbuh pendek (stunting) dapat dicegah sedini mungkin dengan pemberian ASI eksklusif dan MPASI yang benar.

Berdasarkan profil kesehatan Provinsi Lampung, cakupan bayi mendapatkan ASI Ekslusif tahun 2014 sudah memenuhi target yaitu 82,3\%, tetapi turun pada tahun 2015 menjadi 57,70\% (Dinkes Provinsi Lampung, Tahun 2015; 2016). Pada profil kesehatan Indonesia tahun 2016, Provinsi Lampung kembali turun menjadi $22.4 \%$ bayi yang mendapat asi eklusif 0-6 bulan (Dinkes Provinsi Lampung, 2017). Menurut profil kesehatan Provinsi Lampung 2015, angka capaian cakupan bayi mendapat ASI ekslusif per Kabupaten Kota di Lampung, tidak ada satupun Kabupaten Kota yang mencapai target yang diharapkan, cakupan tertinggi ada pada Kabupaten Lampung Selatan $76,01 \%$, cakupan terendah yaitu Kabupaten Pesawaran 18,22\%. Menurut laporan PWS Gizi 
Puskesmas Brenung bahwa 64,4\% ibu mengatakan produksi ASI-nya kurang (Dinkes Provinsi Lampung, 2016).

Berdasarkan hasil pra-survey yang dilakukan di BPM Wilayah Kota Bandar Lampung, didapatkan $54 \%$ ibu nifas yang ASI nya belum keluar pada hari ke 3 atau ke 4 setelah melahirkan sehingga meminta PASI untuk memenuhi kebutuhan nutrisi pada bayinya. Berdasarkan hasil wawancara penulis terhadap petugas yang memberikan perawatan pada ibu setelah melahirkan pada beberapa BPM, diperoleh data sekitar $43 \%$ ibu yang tidak memberikan kolostrumnya segera setelah lahir karena kolostrumnya belum keluar dan tidak dapat memberikan ASI-nya secara on demand (sesuai kebutuan bayi). Penyebab ibu tidak memberikan ASI nya secara on demand antara lain $68 \%$ kolostrumnya tidak keluar pada saat setelah melahirkan dan $56 \%$ mengatakan produksi ASI nya sedikit.

Produksi ASI dapat ditingkatkan salah satu diantaranya dengan mengkonsumsi sayursayuran. Adapun jenis sayuran yang dapat memperbanyak produksi ASI antara lain sayur daun katu, sayur pepaya muda dan sayur daun kelor. Mengkonsumsi sayur daun katu sudah sangat populer di masyarakat dan sering dikonsumsi oleh ibu-ibu yang habis melahirkan. Sedangkan untuk konsumsi sayur pepaya muda dan sayur daun kelor masih jarang dilakukan oleh ibu-ibu menyusui. Pepaya muda dan daun kelor merupakan tumbuhan alam yang berperan sebagai Laktogogum karena dapat meningkatkan dan memperlancar pengeluaran ASI.

Pepaya muda (Carica papaya L.) mengandung saponin, alkaloid, mineral, vitamin dan enzim. Berdasarkan penelitian (Kharisma dkk, 2011) didapatkan bahwa air buah pepaya muda memberikan efek meningkatkan jumlah dan diameter kelenjar mama. Getah (lateks) dari buah papaya muda memiliki efek sama dengan oksitosin pada uterus. Hormon prolaktin dan oksitosin berperan dalam peningkatan produksi air susu. Prolaktin berperan dalam sintesis air susu, sedangkan oksitosin berperan merangsang mioepitel disekitar alveolus untuk berkontraksi sehingga semprotan ASI dapat diteruskan melalui duktus (Manuaba, 2007).

Tanaman daun kelor merupakan bahan makanan lokal yang memiliki potensi untuk dikembangkan dalam kuliner ibu menyusui karena mengandung senyawa fitosterol yang berfungsi meningkatkan dan memperlancar produksi ASI (efek laktogogum). Secara teoritis, senyawa-senyawa yang mempunyai efek laktogogum diantaranya adalah sterol. sterol merupakan senyawa golongan steroid. Menurut hasil penelitian Mutiara (2011) menunjukkan bahwa pemberian tepung daun kelor dapat meningkatkan produksi air susu induk tikus secara signifikan. Pemberian dosis mulai 42 $\mathrm{mg} / \mathrm{kgBB}$ secara signifikan dapat membuat sekresi air susu tikus putih meningkat dan berat badan anak tikus meningkat seiring dengan meningkatnya dosis yang diberikan.

Atas dasar tersebut, maka penulis tertarik untuk melakukan penelitian dengan judul Efektifitas konsumsi sayur papaya muda dan sayur daun kelor terhadap produksi ASI pada ibu post partum primipara di PMB Wilayah Kota Bandar lampung Tahun 2018.

\section{METODE}

Penelitian ini menggunakan metode penelitian kuantitatif (analitik) dengan menggunakan quasi eksperimental design. Populasi studi adalah ibu post partum primipara di PMB Wilayah Kota Bandar Lampung pada bulan Juli s/d Oktober tahun 2018 yang berjumlah 145 orang. Adapun sampel yang digunakan dalam penelitian sebanyak 90 orang yang terdiri dari 30 orang diberi konsumsi sayur pepaya muda, 30 orang diberi sayur daun kelor dan 30 orang sebagai kontrol tanpa diberikan konsumsi sayur pepaya muda dan sayur daun kelor. Kriteria inklusi: (a) Ibu post partum di PMB wilayah Kota Bandar Lampung; (b) Tercatat dalam buku persalinan; (c) Ibu Primipara; (d). Berat badan bayi yang dilahirkan antara 2500 gram s/d 4000 gram, (e) Usia kehamilan aterm, (f) Bayi tidak mengalami kelainan cerna ASI dan (g) Bayi tidak mempunyai cacat bawaan. Sedangkan kriteria ekslusi: (a) Ibu post partum yang tidak melahirkan di PMB wilayah Kota Bandar Lampung; (b) Tidak tercatat dalam buku persalinan, (c) Ibu multipara; (d) Berat badan bayi yang dilahirkan kurang dari 2500 gram dan lebih dari 4000 gram; (e) Usia kehamilan preterm dan post-term, (f) Bayi mengalami kelainan cerna ASI, (g) Bayi memiliki cacat bawaan.

Data yang dikumpulkan menggunakan data primer. Analisa yang digunakan untuk menguji perbedaan 2 variabel antara variabel numerik dengan variabel numerik menggunakan uji statistik "Uji T Sampel Independent". 
HASIL

Analisis Univariat

Tabel 1. Distribusi Usia Ibu Post partum Primipara

\begin{tabular}{|c|c|c|c|c|c|c|c|c|}
\hline \multirow[t]{2}{*}{ Usia } & \multicolumn{2}{|c|}{$\begin{array}{l}\text { Konsumsi Sayur } \\
\text { Pepaya Muda }\end{array}$} & \multicolumn{2}{|c|}{$\begin{array}{l}\text { Konsumsi } \\
\text { Sayur Daun } \\
\text { Kelor } \\
\end{array}$} & \multicolumn{2}{|c|}{$\begin{array}{c}\text { Non Konsumsi Sayur } \\
\text { pepaya Muda Dan } \\
\text { Sayur Daun Kelor }\end{array}$} & \multirow[t]{2}{*}{ Jumlah } & \multirow[t]{2}{*}{$\%$} \\
\hline & $\mathbf{n}$ & $\%$ & $\mathbf{n}$ & $\%$ & $\mathrm{n}$ & $\%$ & & \\
\hline Kurang dari 20 tahun & 5 & 16,7 & 6 & 20 & 3 & 10 & 14 & 15,56 \\
\hline $20-35$ tahun & 25 & 83,3 & 22 & 73,3 & 27 & 90 & 74 & 82,22 \\
\hline Lebih dari 35 tahun & 0 & 0 & 2 & 6,7 & 0 & 0 & 2 & 2,22 \\
\hline Jumlah & 30 & 100 & 30 & 100 & 30 & 100 & 90 & 100 \\
\hline
\end{tabular}

Berdasarkan tabel 1, dari 90 orang ibu post partum primipara yang sebagian besar $(82,22 \%)$

dalam katagori usia reproduktif yaitu usia 20-35 tahun.

Tabel 2. Distribusi Pendidikan Ibu Post partum Primipara

\begin{tabular}{|c|c|c|c|c|c|c|c|c|}
\hline \multirow[t]{2}{*}{ Usia } & \multicolumn{2}{|c|}{$\begin{array}{l}\text { Konsumsi Sayur } \\
\text { Pepaya Muda }\end{array}$} & \multicolumn{2}{|c|}{$\begin{array}{l}\text { Konsumsi Sayur } \\
\text { Daun Kelor }\end{array}$} & \multicolumn{2}{|c|}{$\begin{array}{l}\text { Non Konsumsi Sayur } \\
\text { pepaya Muda dan } \\
\text { Sayur Daun Kelor }\end{array}$} & \multirow[t]{2}{*}{ Jumlah } & \multirow[t]{2}{*}{$\%$} \\
\hline & $\mathbf{n}$ & $\%$ & $\mathbf{n}$ & $\%$ & n & $\%$ & & \\
\hline $\begin{array}{l}\text { Rendah } \\
\text { (SD/SMP) }\end{array}$ & 6 & 20 & 11 & 36,7 & 7 & 23,3 & 24 & 26,7 \\
\hline $\begin{array}{l}\text { Tinggi } \\
\text { (SMA/PT) }\end{array}$ & 24 & 80 & 19 & 63,3 & 23 & 76,7 & 66 & 73,3 \\
\hline Jumlah & 30 & 100 & 30 & 100 & 30 & 100 & 90 & 100 \\
\hline
\end{tabular}

Berdasarkan tabel 2, dari 90 orang ibu post dengan latar belakang pendidikan tinggi partum primipara yang sebagian besar $(73,3 \%)$ (SMA/PT).

Tabel 3. Distribusi Pekerjaan Ibu Post partum Primipara

\begin{tabular}{|c|c|c|c|c|c|c|c|c|}
\hline \multirow[t]{2}{*}{ Usia } & \multicolumn{2}{|c|}{$\begin{array}{c}\text { Konsumsi Sayur } \\
\text { Pepaya Muda }\end{array}$} & \multicolumn{2}{|c|}{$\begin{array}{c}\text { Konsumsi } \\
\text { Sayur Daun } \\
\text { Kelor } \\
\end{array}$} & \multicolumn{2}{|c|}{$\begin{array}{l}\text { Non Konsumsi Sayur } \\
\text { Pepaya Muda dan } \\
\text { Sayur Daun Kelor }\end{array}$} & \multirow[t]{2}{*}{ Jumlah } & \multirow[t]{2}{*}{$\%$} \\
\hline & $\mathbf{n}$ & $\%$ & $\mathbf{n}$ & $\%$ & n & $\%$ & & \\
\hline Bekerja & 3 & 10 & 5 & 16,7 & 8 & 26,7 & 16 & 17,8 \\
\hline $\begin{array}{l}\text { Tidak } \\
\text { Bekerja }\end{array}$ & 27 & 90 & 25 & 83,3 & 22 & 73,3 & 74 & 72,2 \\
\hline Jumlah & 30 & 100 & 30 & 100 & 30 & 100 & 90 & 100 \\
\hline
\end{tabular}

Berdasarkan tabel 3, dari 90 orang ibu sebesar $72,2 \%$ merupakan ibu yang tidak post partum primipara sebanyak 74 orang yaitu bekerja.

Tabel. 4 Distribusi Pengeluaran Kolostrum Ibu Post partum Primipara

\begin{tabular}{|c|c|c|c|c|c|c|c|c|}
\hline \multirow[t]{2}{*}{ Usia } & \multicolumn{2}{|c|}{$\begin{array}{c}\text { Konsumsi } \\
\text { Sayur Pepaya } \\
\text { Muda } \\
\end{array}$} & \multicolumn{2}{|c|}{$\begin{array}{l}\text { Konsumsi Sayur } \\
\text { Daun Kelor }\end{array}$} & \multicolumn{2}{|c|}{$\begin{array}{c}\text { Non Konsumsi Sayur } \\
\text { Pepaya Muda Dan } \\
\text { Sayur Daun Kelor }\end{array}$} & \multirow[t]{2}{*}{ Jumlah } & \multirow[t]{2}{*}{$\%$} \\
\hline & n & $\%$ & $\mathbf{n}$ & $\%$ & n & $\%$ & & \\
\hline $\begin{array}{l}\text { Sudah } \\
\text { Keluar }\end{array}$ & 22 & 73,3 & 21 & 70 & 18 & 6 & 61 & 67,8 \\
\hline $\begin{array}{l}\text { Belum } \\
\text { Keluar }\end{array}$ & 8 & 26,7 & 9 & 30 & 12 & 4 & 29 & 32,2 \\
\hline Jumlah & 30 & 100 & 30 & 100 & 30 & 100 & 90 & 100 \\
\hline
\end{tabular}


Berdasarkan tabel 4, dari 90 orang ibu post partum primipara, sebagian besar $(67,8 \%)$ kolostrumnya sudah keluar.

\begin{tabular}{|c|c|c|c|}
\hline $\begin{array}{l}\mathbf{P} \\
\mathbf{B} \\
\text { B } \\
\text { Il } \\
\text { K }\end{array}$ & $\begin{array}{l}\text { Peningkatan } \\
\text { Berdasarkan } \mathbf{R} \\
\text { Berat Badan B } \\
\text { lbu Post part } \\
\text { Konsumsi Sayu }\end{array}$ & $\begin{array}{l}\text { Produk } \\
\text { ta-Rata I } \\
\text { yi Usia 3( } \\
\text { im Prim } \\
\text { Pepaya M }\end{array}$ & 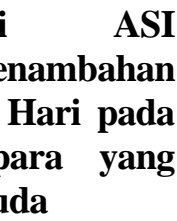 \\
\hline \multirow{2}{*}{$\begin{array}{c}\text { Konsumsi } \\
\text { Sayur }\end{array}$} & \multicolumn{3}{|c|}{$\begin{array}{c}\text { Rata-Rata Penambahan Berat } \\
\text { Badan Bayi }\end{array}$} \\
\hline & $\begin{array}{c}\text { Usia 30 } \\
\text { Hari (gram) } \\
\end{array}$ & $\begin{array}{c}\text { Minimal } \\
\text { (gram) }\end{array}$ & $\begin{array}{l}\text { Maksimal } \\
\text { (gram) }\end{array}$ \\
\hline $\begin{array}{l}\text { Pepaya } \\
\text { Muda }\end{array}$ & 930 & 500 & 1500 \\
\hline
\end{tabular}

Berdasarkan tabel 5, peningkatan produksi ASI berdasarkan rata-rata penambahan berat badan bayi usia 30 hari pada ibu post partum primipara yang mengkonsumsi sayur pepaya muda sebanyak 930 gram, dengan penambahan berat badan minimal 500 gram dan penambahan berat badan maksimal 1500 gram.

Tabel 6. Peningkatan Produksi ASI Berdasarkan Rata-Rata Penambahan Berat Badan Bayi Usia 30 Hari pada Ibu Post partum Primipara yang Konsumsi Sayur Daun Kelor

\begin{tabular}{cccc}
\hline \multirow{2}{*}{$\begin{array}{c}\text { Konsumsi } \\
\text { Sayur }\end{array}$} & \multicolumn{3}{c}{ Rata-Rata Kenaikan } \\
\cline { 2 - 4 } & $\begin{array}{c}\text { Usia 30 Hari } \\
\text { (gram) }\end{array}$ & $\begin{array}{c}\text { Minimal } \\
\text { (gram) }\end{array}$ & $\begin{array}{c}\text { Maksimal } \\
\text { (gram) }\end{array}$ \\
\hline Daun & 1270 & 700 & 2300 \\
Kelor & 1270 & & \\
\hline
\end{tabular}

Berdasarkan tabel 6 , peningkatan produksi ASI berdasarkan rata-rata penambahan berat badan bayi usia 30 hari pada ibu post partum primipara yang mengkonsumsi sayur daun kelor sebanyak 1270 gram, dengan penambahan berat badan minimal 700 gram dan penambahan berat badan maksimal 2300 gram.

Tabel 7. Peningkatan Produksi ASI Berdasarkan Rata-Rata Penambahan Berat Badan Bayi Usia 30 Hari pada Ibu Post partum Primipara yang Tidak Konsumsi Sayur Pepaya Muda dan Sayur Daun Kelor

\begin{tabular}{|c|c|c|c|}
\hline \multirow[b]{2}{*}{$\begin{array}{c}\text { Konsumsi } \\
\text { Sayur }\end{array}$} & \multicolumn{3}{|c|}{ Rata-Rata Kenaikan Berat Badan } \\
\hline & $\begin{array}{c}\text { Usia 30 } \\
\text { Hari } \\
\text { (gram) }\end{array}$ & $\begin{array}{c}\text { Minimal } \\
\text { (gram) }\end{array}$ & $\begin{array}{c}\text { Maksimal } \\
\text { (gram) }\end{array}$ \\
\hline $\begin{array}{l}\text { Tidak konsumsi } \\
\text { sayur pepaya } \\
\text { muda dan sayur } \\
\text { daun kelor }\end{array}$ & 826,67 & 500 & 1300 \\
\hline
\end{tabular}

Berdasarkan tabel 7, peningkatan produksi ASI berdasarkan rata-rata penambahan berat badan bayi usia 30 hari pada ibu post partum primipara yang tidak mengkonsumsi sayur pepaya muda dan sayur daun kelor sebanyak 826,67 gram, dengan penambahan berat badan minimal 500 gram dan kenaikan berat badan maksimal 1300 gram.

\section{Analisis Bivariat}

Tabel 8. Perbedaan Peningkatan Produksi ASI Berdasarkan Penambahan Berat Badan Bayi Usia 30 Hari pada Ibu Post partum Primipara antara Konsumsi Sayur Pepaya Muda dan Tidak Mengkonsumsi Sayur Pepaya Muda dan Sayur Daun Kelor

\begin{tabular}{lrrr}
\hline \multicolumn{1}{c}{ Konsumsi } & Mean & $\begin{array}{c}\text { Standar } \\
\text { Deviasi }\end{array}$ & $\begin{array}{c}\boldsymbol{p} \\
\text { value }\end{array}$ \\
\cline { 1 - 3 } Sayur Pepaya Muda & 930 & 364,975 & \\
\cline { 1 - 2 } Tidak konsumsi & & & \\
Sayur Pepaya Muda & 826,67 & 204,995 & 0,182 \\
Dan Sayur Daun & & & \\
Kelor & & & \\
\hline
\end{tabular}

Berdasarkan tabel 8, hasil uji Independent Samples Test, didapatkan $p$-value $=0,182>\alpha=0,05$ yang artinya tidak ada perbedaan yang signifikan peningkatan produksi ASI pada ibu post partum primipara antara yang konsumsi sayur pepaya muda dengan yang tidak mengkonsumsi sayur pepaya muda dan sayur daun kelor.

Tabel 9. Perbedaan Peningkatan Produksi ASI Berdasarkan Penambahan Berat Badan Bayi Usia 30 Hari pada Ibu Post partum Primipara Antara yang Konsumsi Sayur Daun Kelor dan Tidak Mengkonsumsi Sayur Pepaya Muda dan Sayur Daun Kelor

\begin{tabular}{lrcr}
\hline Konsumsi & Mean & $\begin{array}{c}\text { Standar } \\
\text { Deviasi }\end{array}$ & p-value \\
\cline { 1 - 3 } Sayur Daun Kelor & 1270 & 383,406 & \\
\cline { 1 - 3 } Tidak konsumsi & & & \\
Sayur Pepaya & 826,67 & 204,995 & 0,000 \\
Muda Atau Sayur & & & \\
Daun Kelor & & & \\
\hline
\end{tabular}

Berdasarkan tabel 9, hasil uji Independent Samples Test, didapatkan $p$-value $=0,000<\alpha=0,05$ yang artinya ada perbedaan yang signifikan peningkatan produksi ASI pada ibu post partum primipara antara yang konsumsi sayur daun kelor dengan yang tidak mengkonsumsi sayur pepaya muda dan sayur daun kelor. 
Tabel 10. Efektifitas Konsumsi Sayur Pepaya Muda dan Sayur Daun Kelor terhadap Peningkatan Produksi ASI Berdasarkan Penambahan Berat Badan Bayi Usia 30 Hari

\begin{tabular}{lrrr}
\multicolumn{1}{c}{ Konsumsi } & Mean & $\begin{array}{c}\text { Standar } \\
\text { Deviasi }\end{array}$ & p-value \\
\hline Pepaya Muda & 930 & 364,975 & 0,001 \\
\cline { 1 - 3 } Daun Kelor & 1270 & 383,406 & \\
\hline
\end{tabular}

Berdasarkan tabel 10, hasil uji Independent Samples Test, didapatkan $p$-value $=0,001<\alpha=0,05$ yang artinya ada perbedaan yang signifikan peningkatan produksi ASI pada ibu post partum primipara yang konsumsi sayur daun kelor dibandingkan dengan ibu post partum yang mengkonsumsi sayur pepaya muda berdasarkan penambahan berat badan bayi setelah usia 30 hari, dengan rata-rata penambahan berat badan bayi pada ibu post partum primipara yang mengkonsumsi sayur pepaya daun kelor sebanyak 1270 gram dan pada ibu post partum primipara yang mengkonsumsi sayur pepaya muda didapatkan rata-rata penambahan berat badan sebanyak 930 gram. Hal ini menggambarkan bahwa konsumsi sayur daun kelor lebih efektif meningkatkan produksi ASI dibandingkan dengan mengkonsumsi sayur pepaya muda.

\section{PEMBAHASAN}

\section{Efektifitas Konsumsi Sayur Pepaya Muda dan Sayur Daun Kelor}

Hasil penelitian didapatkan bahwa mengkonsumsi sayur daun kelor lebih efektif meningkatkan produksi ASI dibandingkan dengan mengkonsumsi sayur pepaya muda dengan p-value 0,001. Hal ini dapat dilihat dengan indikator rata-rata penambahan berat badan bayi usia 30 hari pada ibu post partum primipara yang mengkonsumsi sayur daun kelor lebih banyak bila dibandingkan dengan ibu post partum yang mengkosumsi sayur pepaya muda. Rata-rata penambahan berat badan bayi pada ibu yang mengkonsumsi sayur daun kelor sebanyak 1270 gram, sedangkan pada ibu post partum yang mengkonsumsi sayur pepaya muda sebanyak 930 gram. Hal ini mendukung hasil penelitian Zakaria, dkk (2016) yang mengatakan bahwa mengkonsumsi daun kelor dapat meningkatkan kuantitas ASI dengan p-value 0,001.

Pada ibu post partum primipara yang mengkonsumsi sayur pepaya muda bila dibandingkan dengan yang tidak mengkonsumsi sayur pepaya muda maupun sayur daun kelor berdasarkan hasil penelitian tidak menunjukkan perbedaan yang signifikan pada produksi ASI nya dengan $p$-value 0,182 dan dilihat dari ratarata penambahan berat badan bayi pada usia 30 hari tidak berbeda jauh yaitu 930 gram dan 826,27 gram. Sedangkan pada ibu post partum primipara yang mengkonsumsi sayur daun kelor bila dibandingkan dengan yang tidak mengkonsumsi sayur pepaya muda dan sayur daun kelor menunjukkan perbedaan yang signifikan pada produksi ASI nya dengan $p$-value 0,000 dan dilihat dari rata-rata penambahan berat badan bayi pada usia 30 hari menunjukkan perbedaan yang cukup banyak yaitu 1270 gram dan 826,27 gram.

Pada penelitian ini kelompok ibu post partum pertama dianjurkan untuk mengkonsumsi sayur daun kelor sebanyak 100 gram per hari dan kelompok ibu post partum kedua dianjurkan untuk mengkonsumsi sayur pepaya muda sebanyak 100 gram per hari, dan masing-masing responden mengkonsumsi sayur daun kelor atau sayur pepaya muda selama 30 hari. Selanjutnya penambahan berat badan bayi diketahui dengan melakukan penimbangan pada hari ke 14 , hari ke 21 dan hari ke 30 dan untuk mengetahui penambahan berat badan bayi, hasil pengukuran berat badan setelah 30 hari dikurangi dengan berat badan lahir.

Selain itu juga pada penelitian ini, perlakuan terhadap responden sama dengan kelompok kontrol (yang tidak mengkonsumsi sayur pepaya muda dan sayur daun kelor) yaitu dilakukan inisiasi menyusui dini setelah bayi lahir, mengkonsumsi makanan standar untuk menu ibu nifas dan menyusui bayi sesuai dengan kebutuhan bayi (on demand).

Pada kelompok kontrol terdapat perbedaan peningkatan produksi ASI berdasarkan penambahan berat badan bayi setelah usia 30 hari, dimana rata-rata penambahan berat badan bayinya lebih sedikit yaitu 826,67 gram bila dibandingkan dengan ibu yang mengkonsumsi sayur daun kelor sebanyak 1270 gram dan yang mengkonsumsi sayur pepaya muda sebanyak 930 gram.

Pada daun kelor dan pepaya muda merupakan tanaman yang mengandung laktogogum yang memiliki potensi dalam menstimulasi hormon oksitoksin dan prolaktin seperti alkaloid, polifenol, steroid, flavonoid dan substansi lainnya paling efektif dalam meningkatkan dan memperlancar produksi ASI. Reflek prolaktin secara hormonal untuk memproduksi ASI, waktu bayi menghisap puting payudara ibu, terjadi rangsangan neorohormonal 
pada puting susu dan areola ibu. Rangsangan ini diteruskan ke hipofisis melalui nervos vagus, kemudian ke lobus anterior. Dari lobus ini akan mengeluarkan hormon prolaktin, masuk ke peredaran darah dan sampai pada kelenjarkelenjar pembuat ASI. Kelenjar ini akan terangsang untuk menghasilkan ASI.

Berdasarkan hasil studi Mutiara, (2011) melaporkan bahwa daun kelor mengandung senyawa fitosterol diantaranya kampesterol, stigmasterol, dan $\beta$-sitosterol yang bersifat laktagogum yang dapat meningkatkan produksi ASI. Hasil penelitiannya menunjukkan pemberian tepung kelor dapat meningkatkan produksi air susu induk tikus secara nyata seiring dengan peningkatan konsentarsi yang diberikan. ASI merupakan cairan kompleks yang mengandung berbagai unsur penting yaitu karbohidrat, protein, lemak, vitamin larut air, vitamin larut lemak, mineral, dan sel-sel epitel. Secara umum, kadar gizi ASI tinggi saat lahir dan akan berkurang selama periode laktasi.

Pemanfaatan buah pepaya muda pada masyarakat sudah banyak ditemui, seperti baik untuk kesehatan mata, baik untuk pencernaan, yang digunakan untuk membuat sayur karena kandungan protein dan vitamin, serta dimakan untuk memperlancar dan memperbanyak produksi ASI. Pengolahan buah pepaya muda pada masyarakat biasa dilakukan dengan cara direbus, diurap, dikukus dan dioseng-oseng. Buah pepaya menjadi bahan makanan yang memiliki banyak manfaat dan mudah didapatkan oleh masyarakat karena bisa dengan mudah ditanam di pekarangan rumah. Pemanfaatan buah pepaya yang dapat meningkatkan produksi ASI, berkontribusi terhadap peningkatan/penambahan berat badan bayi.

Keberhasilan menyusui tergantung dari produksi ASI yang dihasilkan oleh ibu setelah melahirkan. ASI diproduksi dari hasil kerjasama antara faktor hormonal. Hormon estrogen berperan menjaga tekstur dan fungsi payudara membesar dan merangsang pertumbuhan kelenjar ASI. ASI diproduksi setiap saat sebelum, selama dan sesudah mayi menyusu. ASI yang telah diproduksi disimpan dalam payudara ibu. Pada minggu bulan terakhir kehamilan, kelenjarkelenjar produksi ASI mulai menghasilkan ASI. Apabila tidak ada kelainan pada hari pertama sejak bayi lahir akan dapat menghasilkan 50-100 $\mathrm{ml}$ sehari dan akan terus bertambah sehingga mencapai sekitar 450-450 ml pada waktu mencapai usia minggu kedua. Produksi ASI yang mencukupi atau berlebihan akan berpengaruh terhadap peningkatan berat badan bayi.
Faktor-faktor yang mempengaruhi produksi air susu ibu salah satunya adalah asupan makanan. Makanan yang dikonsumsi ibu memengaruhi produksi ASI. Bila makanan yang disantap mengandung gizi seimbang dan teratur, diharapkan kelenjar pembuat ASI dapat bekerja optimal. Maka penuhi kebutuhan kalori, protein, lemak, dan vitamin serta mineral yang cukup. Apabila ibu yang sedang menyusui bayinya tidak mendapat tambahan makanan tentu akan mengakibatkan terjadinya kemunduran dalam pembuatan dan produksi ASI. Makanan tambahan yang dianjurkan selama menyusui mengandung unsur protein dan makanan sebagai sumber vitamin. Berdasarkan beberapa penelitian, konsumsi sayur daun katu, papaya muda dan sayur daun kelor dapat membantu produksi ASI.

Pada penelitian Istiqomah, dkk (2015), disebutkan bahwa berdasarkan hasil penelitian didapatkan produksi ASI sebelum konsumsi buah papaya rata-rata frekuensi menyusui adalah 5,7 kali dengan standar deviasi 0,80131 dan setelah mengkonsumsi buah papaya rata-rata frekunesi menyusui mengalami peningkatan menjadi 9,75 kali dengan standar deviasi 0,78640.

Pepaya muda (Carica papaya L.) mengandung saponin, alkaloid, mineral, vitamin dan enzim. Berdasarkan penelitian (Kharisma dkk, 2011) didapatkan bahwa air buah pepaya muda memberikan efek meningkatkan jumlah dan diameter kelenjar mama. Getah (lateks) dari buah papaya muda memiliki efek sama dengan oksitosin pada uterus. Hormon prolaktin dan oksitosin berperan dalam peningkatan produksi air susu. Prolaktin berperan dalam sintesis air susu, sedangkan oksitosin berperan merangsang mioepitel disekitar alveolus untuk berkontraksi sehingga semprotan ASI dapat diteruskan melalui duktus (Manuaba, 2007).

Selain mengkonsumsi sayur pepaya muda, mengkonsumsi sayur daun kelor juga dapat meningkatkan produksi air susu ibu. Pada penelitian Zakaria, Veni Hadju, Suryani As'ad dan Burhanuddin Bahar, disebutkan bahwa kuantitas ASI meningkat pada kedua kelompok yaitu yang mendapatkan ekstrak daun kelor (EK) dan tepung daun kelor (TK). Peningkatan kuantitas ASI berbeda signifikan antara kelompok EK dan TK (masing-masing 263 \pm 129 to $600 \pm 120, p=0,001)$. Peningkatan kuantitas ASI berbeda signifikan antara kelompok EK dan TK. Pemberian EK dan TK dapat meningkatkan volume ASI, peningkatan volume ASI lebih tinggi pada kelompok yang mendapat EK disbanding TK, tetapi tidak berpengaruh terhadap kualitas ASI (zat besi, vitamin C dan vitamin E). 
Tanaman daun kelor merupakan bahan makanan lokal yang memiliki potensi untuk dikembangkan dalam kuliner ibu menyusui karena mengandung senyawa fitosterol yang berfungsi meningkatkan dan memperlancar produksi ASI (efek laktogogum). Secara teoritis, senyawa-senyawa yang mempunyai efek laktogogum diantaranya adalah sterol. sterol merupakan senyawa golongan steroid. Menurut hasil penelitian Mutiara menunjukkan bahwa pemberian tepung daun kelor dapat meningkatkan produksi air susu induk tikus secara signifikan. Pemberian dosis mulai 42 $\mathrm{mg} / \mathrm{kgBB}$ secara signifikan dapat membuat sekresi air susu tikus putih meningkat dan berat badan anak tikus meningkat seiring dengan meningkatnya dosis yang diberikan.

Berdasarkan hasil penelitian bahwa konsumsi sayur daun kelor lebih efektif untuk meningkatkan produksi ASI berdasarkan berat badan bayi pada masa 30 hari pertama kehidupannya dibandingkan konsumsi sayur pepaya muda. Peningkatan berat badan bayi merupakan indikator untuk menentukan pertumbuhan dan perkembangan bayi terutama pada 6 bulan pertama kehidupannya sehingga sangat tergantung dari produksi air susu ibu yang berdampak terhadap terpenuhinya kebutuhan bayi selama masa tersebut, karena pada masa tersebut bayi hanya tergantung pada air susu ibunya. Kecukupan ASI pada bayi ditandai dengan peningkatan berat badan bayi dalam masa 6 bulan pertama kehidupannya. Oleh karena itu dianjurkan pada ibu masa menyusui untuk menambahkan sayur daun kelor dalam menu makanannya untuk memperbanyak produksi ASI dan memperlancar pengeluaran ASI sehingga kebutuhan bayi akan ASI pada masa 6 bulan kehidupannya terpenuhi karena pada masa

\section{DAFTAR PUSTAKA}

Dinkes Provinsi Lampung. (2015). Profil Kesehatan Provinsi Lampung Tahun 2014. Bandar Lampung.

Dinkes Provinsi Lampung. (2016). Profil Kesehatan Provinsi Lampung Tahun 2015. Bandar Lampung.

Dinkes Provinsi Lampung. (2017). Profil Kesehatan Provinsi Lampung Tahun 2016. Bandar Lampung.

Istiqomah, S. B. T., Wulanadari, D. T., \& Azizah, N. (2015). Pengaruh Buah Pepaya terhadap Kelancaran Produksi ASI pada Ibu Menyusui di Desa Wonokerto Wilayah tersebut merupakan masa golden period dan bayi hanya tergantung terhadap pemenuhan ASI. Atas dasar tersebut, penulis menyarankan kepada tenaga kesehatan terutama bidan dan perawat untuk memotivasi ibu menyusui agar pada menu makanannya lebih sering ditambahkan dengan sayur daun kelor dan selalu mengkonsumsi sayur daun kelor pada periode menyusui agar produksi air susu meningkat. Selain itu juga dapat menjadi masukan bagi organisasi profesi Kota Bandar Lampung untuk memprogramkan kegiatan sosialisasi tentang manfaat mengkonsumsi sayur daun kelor terhadap peningkatan produksi ASI.

\section{SIMPULAN}

1. Rata-rata penambahan berat badan bayi usia 30 hari dari ibu yang mengkonsumsi sayur pepaya muda yaitu 930 gram.

2. Rata-rata penambahan berat badan bayi usia 30 hari dari ibu yang mengkonsumsi sayur daun kelor yaitu 1270 gram.

3. Rata-rata penambahan berat badan bayi usia 30 hari pada ibu yang tidak mengkonsumsi sayur pepaya muda dan sayur daun kelor yaitu 826,27 gram.

4. Terdapat efektifitas pemberian sayur daun kelor dibandingkan dengan pemberian sayur pepaya muda terhadap produksi ASI berdasarkan penambahan berat badan bayi pada usia 30 hari dengan $p$ value 0,001 , sehingga dapat ditarik kesimpulan bahwa konsumsi sayur daun kelor pada ibu post partum primipara dalam waktu 30 hari lebih efektif meningkatkan produksi ASI bila dibandingkan dengan mengkonsumsi sayur pepaya muda.

Puskesmas Peterongan Jombang Tahun 2014. Eduhealth, 5(2).

Kharisma, Y., Ariyoga, A., \& Sastramihardja, H. S. (2011). Efek ekstrak air buah pepaya (Carica papaya L.) muda terhadap gambaran histologi kelenjar mamma mencit laktasi. Majalah Kedokteran Bandung, 43(4), 160-165.

Manuaba. (2007). Pengantar Kuliah Obstetri. Jakarta: Buku Kedokteran EGC.

Oktova, R. (2017). Determinan yang Berhubungan dengan Pemberian MP-ASI Dini pada Bayi Usia 0-6 Bulan. Jurnal Kesehatan, 8(1), 84-90. 
Prasetyaningati, D. (2018). Hubungan faktor kesehatan ibu postpartum dengan penyapihan dini di desa sidorejo kecamatan pare kabupaten kediri. Jurnal Keperawatan, 16(1).

Salfina, Elmida. (2003). Hubungan Pengetahuan dan Perilaku Ibu Dalam Pemberian ASI Ekslusif di Kecamatan Tebet. Jurnal Kesehatan Masyarakat.
Mutiara T. (2011). Uji Efek Pelancar ASI Tepung Daun Kelor (Moringa Oleifera (Lamk)) Pada Tikus Putih Galur Wistar. (Disertasi, Universitas Brawijaya).

Zakaria, Z., Hadju, V., As' ad, S., \& Bahar, B.. (2016). Pengaruh Pemberian Ekstrak Daun Kelor Terhadap Kuantitas Dan Kualitas Air Susu Ibu (ASI) Pada Ibu Menyusui Bayi 0-6 Bulan. Media Kesehatan Masyarakat Indonesia, 12(3), 161-169. 